\title{
An in vitro study of the spore densities effect of trichoderma spp. As biocontrol agent for fusarium wilt in cayenne pepper (Capsicum sp.)
}

\author{
Tsania Taskia Nabila11, Ika Afifah Nugraheni2 ${ }^{*}$, Rais Sulistyo Widiyatmoko ${ }^{3}$, \\ Wiwit Probowati ${ }^{4}$ \\ ${ }^{1,2}$ Biotechnology Universitas ‘Aisyiyah Yogyakarta, 63 Siliwangi Ringroad Barat Ave Nogotirto Gamping 55592, \\ Sleman, Indonesia \\ ${ }^{3}$ Chairman of Quality Department, Laboratorium Hama dan Penyakit Tanaman (LPHPT), Kauman Wijirejo Pandak, \\ Bantul 55761, Indonesia \\ ${ }^{4}$ Laboratory of Plant Virology, Faculty of Agriculture, Saga University Japan \\ ${ }^{1}$ tazkia27062000@gmail.com; ${ }^{2}$ ikaafifah@unisayogya.ac.id* ; ${ }^{3}$ kochan2rosirr@yahoo.com; \\ ${ }^{4} 20976002 @$ edu.cc.saga-u.ac.jp \\ *corresponding author
}

Submission date: 20 Maret 2021, Receipt date: 8 April 2021, Publication date: 1 Juli 2021

\begin{abstract}
Root disease controlling has been a challenge in increasing plant productivity. The soilborne pathogens become the main concern which mostly infects the root surface. One of the most common soil-borne pathogens is Fusarium oxysporum $\left(F_{0}\right)$. Cayenne pepper (Capsicum sp.) is one of the most abundant commodities and contributes significantly to the economy. This plant is also susceptible to Fusarium wilt infection. The use of endophytic fungi as biocontrol agents is an alternative against soil-borne pathogens, one of which is Trichoderma spp. fungi. This study aimed to determine the effectiveness of various spore densities of Trichoderma spp. against the pathogen Fo. The research was conducted through an in vitro study by antagonistic testing between spore suspensions of Trichoderma spp. $\left(10^{3}, 10^{5}\right.$, and $10^{7}$ spores $\left./ \mathrm{mL}\right)$ with $\mathrm{Fo}$. The results showed the density of $10^{7}$ spores $/ \mathrm{mL}$ gave the highest percentage of inhibition (54.59\%) compared to spore density of $10^{3}(35.27 \%)$ and $10^{5}$ spores $/ \mathrm{mL}(44.44 \%)$. The spore density of $10^{7}$ spores $/ \mathrm{mL}$ gave a significant difference in response to the density of other spores according to the BNT test at a significance level of $5 \%$ and was able to inhibit the growth of Fo more than $50 \%$. The results of this study are expected to be a reference for the formulation of Trichoderma spp. which is ideal for controlling Fo pathogens in the fields.
\end{abstract}

Keywords: biocontrol agent, trichoderma spp., fusarium oxysporum, antagonistic test 


\section{INTRODUCTION}

Root disease controlling has been a challenge in increasing plant productivity. The soil-borne pathogens become the main concern which mostly infects the root surface (Suryanto et al., 2010). Soil-borne pathogens can disrupt the balance of microbial diversity in the rhizosphere and endosphere. Soil pathogens can be bacteria, fungi, or nematodes which often work synergistically and cause a drastic reduction in crop yields (Wolfgang et al., 2019).

Cayenne pepper belongs to the Solanaceae family and the genus Capsicum. Cayenne pepper is one of the most abundant commodities and gives a significant impact on the local and national economy in various countries (Khan et al., 2018). Indonesia is the fourth largest chili-producing country in the world. Cayenne pepper in Indonesia occupies $20 \%$ of the total vegetable land with a production output of $12 \%$ (Mariyono \& Sumarno, 2015). The annual production of cayenne pepper in several areas of Java Island from 2017 to 2019 ranges from 45 to 34,589 quintals and always fluctuates due to some factors such as climate change and environmental stress. Cayenne pepper is also the second-largest contributor to inflation in Indonesia after red chili, which is $0.16 \%$ of the average total inflation of 3.096\% in 2019 (Badan Pusat Statistik, 2020a, 2020b).

The presence of biotic stress in the form of soil-borne pathogens like Fo causes a decrease in Indonesian cayenne pepper. This fungus can infect the host plant leads to fusarium wilt disease. Fo belongs to the phylum Ascomycota and the genus Fusarium. In this genus, there are pathogenic and non-pathogenic fungi. The morphology of Fo is nonseptate microconidia formed on monophyalid conidiophores with short stalks. However, species identification in the genus Fusarium is still a challenge because of genetic and environmental influences that cause variations in phenotypic and morphological expressions (Fourie et al., 2011).

Fo has infected more than 120 types of agricultural and horticultural plants, such as the Solanaceae family, melons, bananas, kapok trees, strawberries, tobacco, vanilla, lilies, and so on (Rana et al., 2017). Symptoms of plants affected by Fo are presented in Figure 1.

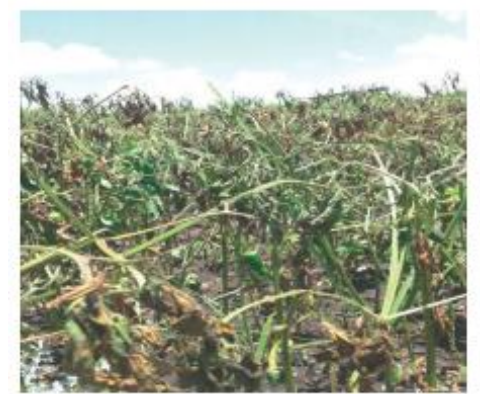

a.

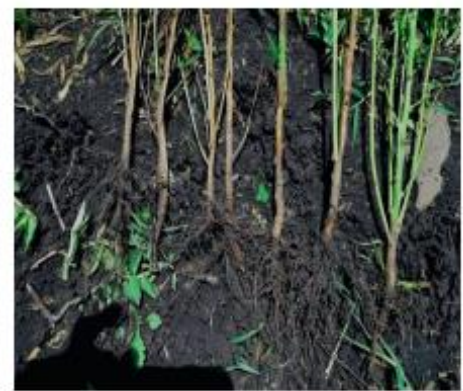

D. 


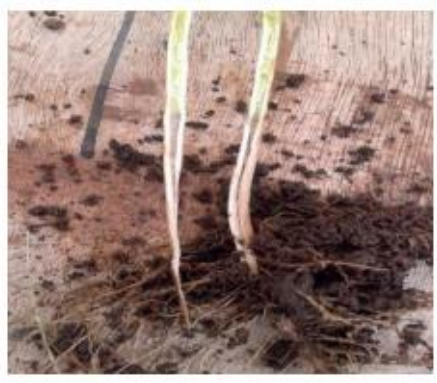

c.

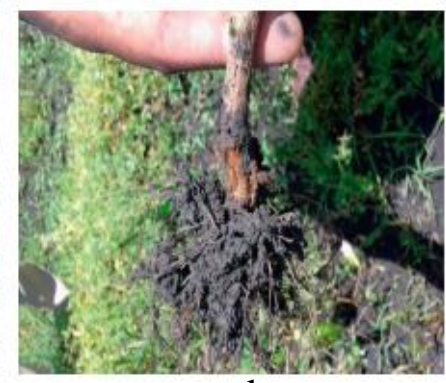

d.

Figure 1. Symptoms of fusarium wilt are found in (a.) leaves, (b.) outer stems, (c.) systemic symptoms of Fo, (d.) roots (Source: Oljira \& Berta (2020))

Specific symptoms of plants that are affected by Fo decay and theblack necrotic spots on the roots and lower stems are formed, precisely in the xylem, then spread to the top of the plant causing wilting, transparent leaf bones, epinasty, stunting, and yellowing on old leaves (Figure 1. (a-b)) (Edel-Hermann \& Lecomte, 2019; Oljira \& Berta, 2020). These soil-borne pathogens cause seedlings to die, grow abnormally, and make host plants agents of transmission of pathogens to other host plants.

Various attempts have been made to inhibit the growth of Fo. They include chemical methods in the form of biocides such as methyl bromide, benomyl, and carbendazim which are applied before the planting process. Biocides are only able to prevent Fo infection and often accumulate in the food chain so that they are potentially toxic. Another method is the heat sterilization method on soil that is non-selective and can reduce soil quality. Genetic engineering methods in plants are also often carried out so that plants have genes encoding disease resistance. However, the expression of this resistance gene generally does not consistent and Fo can potentially mutate so that these fungi become resistant (de Lamo \& Takken, 2020).

The use of endophytic fungi as biocontrol agents becomes an alternative method against soil-borne pathogens. One of the most commonly used biocontrol agents against Fo is the fungus Trichoderma spp. This fungus belongs to the phylum Ascomycota, class Sordariomycetes, order Hypocreales, and family Hypocreaceae (Chaverri et al., 2016). Trichoderma spp. live and reproduce in the rhizosphere. These fungi can suppress the growth of pathogenic fungi through the mechanism of mycoparasitism and are classified as a saprotrophic because it generally obtains nutrients from the decomposition process of plant organic matter (Chaverri \& Samuels, 2013).

Trichoderma spp. act as plant growth-promoting rhizofungi (PGPF) and biological agents for plant pests and diseases. Biological control agents are natural agents that play a role in reducing the population level of pests or pathogens by using natural enemies in the form of living things and involving humans in the treatment. They do not pollute the environment when compared to chemical methods, otherwise, they can fight various types of pathogenic microorganisms and protect plants (Holmes et al., 2016).

Trichoderma spp. perform mycoparasitism mechanism and are saprotrophs, so they act as a parasite for soil-borne pathogens to obtain nutrients. They also act as avirulent endosymbionts in stems, especially in the cambium and phloem, thereby potentially reducing the population of Fo pathogens that similarly attack plant roots and stems (Chaverri \& Samuels, 2013; Holmes et al., 2016). Then Trichoderma spp. receive 
nutrients from root exudates and provide feedback for plants against all types of biotic and abiotic stresses. Mechanisms of Trichoderma spp. as antagonistic agents against soilborne pathogenic fungi include mycoparasitism, production of antibiotics, inducing plant resistance, and competition for nutrients (de Lamo \& Takken, 2020).

Trichoderma spp. has proven its effectiveness in inhibiting various types of soilborne pathogens. Bhat et al. (2016) found that Trichoderma spp. could inhibit the growth of Fo in chili plants by $0-28.6 \%$. T. viridae and T. harzianum had the highest level of protection against Fo, which was 27-35\%. The results of research by Moosa et al., (2017) showed that $T$. viridae species were able to inhibit Fo activity in tomato plants better than T. harzianum, namely $34.96 \%$ in T. viridae and $29.27 \%$ in T. harzianum. Other studies showed the effectiveness of Trichoderma spp., as reported by Li et al. (2016). They revealed that the T. asperellum strain ZJSX5003 could inhibit the pathogen Fusarium graminearum on maize stems by $71 \%$. This was due to the ability of Trichoderma spp. produce hydrolytic enzymes and secrete secondary metabolites such as peptaibols, polyketides, pyrones, terpenes, and several types of polypeptides.

Based on the problem that has been described, this study raised the issue of cayenne pepper production due to the biotic stress of soil-borne pathogens Fo. This fungus was tested in vitro using a biocontrol agent of the PGPF type Trichoderma spp. The given treatment was several spore densities of Trichoderma spp., so it was hoped that the variety spore densities can well inhibit Fo with different percentages. The methods of this research were designed through modification of two references by the authors. This study aimed to determine the effectiveness of several spore densities of Trichoderma spp. as a biocontrol agent for Fo in cayenne pepper. The results of this study are expected to be a reference for the formulation of Trichoderma spp. which is ideal for controlling Fo pathogens in the fields. Trichoderma spp. as biocontrol agent can potentially inhibit the Fo with no side effects in both environment and health so that the cayenne pepper can constantly produce to support the national economy.

\section{RESEARCH METHODS}

This research was held at the phytopathology laboratory LPHPT, Special Region of Yogyakarta, Indonesia. The research method was compiled based on the result of personal modifications: the Indonesian National Standard (SNI) protocol and Pratiwi et al. (2013)

\section{Main Tools and Growth Media Preparation}

The steps of this part were presented in Figure 2 (a-b). Potato Dextrose Agar (PDA) media was made by weighing $300 \mathrm{~g}$ of peeled potatoes and then cut into small pieces. The potatoes were put into a saucepan and $700 \mathrm{~mL}$ of distilled water was added. They were boiled while stirring until the potatoes soften. They were filtered and the filtrate was used. It was added by $7.5 \mathrm{~g}$ of agar and $10 \mathrm{~g}$ of dextrose. The solution was stirred while heated over low heat. The liquid PDA was put into a $150 \mathrm{~mL}$ Erlenmeyer.

A total of 6 test tubes were prepared, then $10 \mathrm{~mL}$ of distilled water was pipetted into two test tubes, while the other four test tubes contained $9 \mathrm{~mL}$ of distilled water. Test tubes containing distilled water, measuring pipettes of $1 \mathrm{~mL}$, Petri dishes with a diameter of $9 \mathrm{~cm}$, and PDA media were sterilized in an autoclave at $121^{\circ} \mathrm{C}$ and $1 \mathrm{~atm}$ pressure for 20 minutes as shown in Figure 2c. Especially for PDA media and distilled 
water, they were sterilized twice to be completely sterile. PDA was then poured into all Petri dishes aseptically.

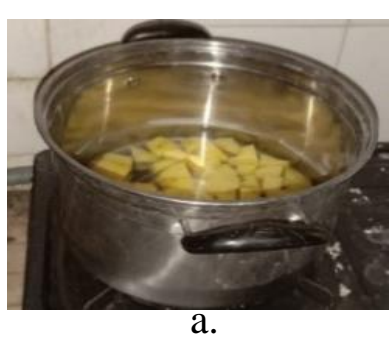

a.

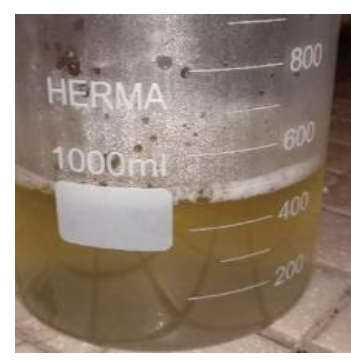

b.

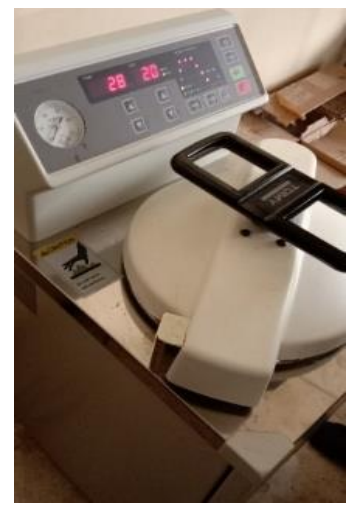

c.

Figure 2. PDA-making process. (a.) The process of boiling potatoes, (b.) The result of boiled potatoes that were added to dextrose and agar, (c.) The autoclaving process at $121^{\circ} \mathrm{C}$ at a pressure of 1 atm for 20 minutes

\section{Trichoderma spp. And Fo Cultivation}

The cultivation aimed to equalize the age of the two isolates. Individual isolates were cultivated in slanted PDA. The two isolates were incubated for seven days at room temperature $\left(25-30^{\circ} \mathrm{C}\right)$.

\section{Spore Density Calculation of Trichoderma spp. (Personal Modifications \&} Pratiwi et al. (2013))

A $0.1 \%$ TWEEN 80 solution was added to five test tubes containing sterile distilled water and then vortexed briefly. Both test tubes containing $10 \mathrm{~mL}$ of sterile distilled water were taken $5 \mathrm{~mL}$ each and inserted into the Trichoderma spp isolate, as well as Fo. The two isolates were completely dredged using an inoculation loop and transferred back to each of the test tubes so that a dilution of $10^{0}$ was obtained. Trichoderma spp. isolates. then serially diluted to $10^{-4}$, while for isolate Fo only up to a dilution of $10^{\circ}$. Each dilution was carried out aseptically and the suspensions were vortexed for 3 minutes. The preparation of this spore count is presented in Figure 3. (a-b). 


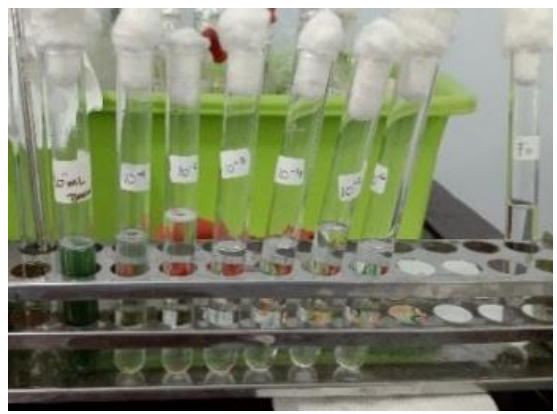

a.

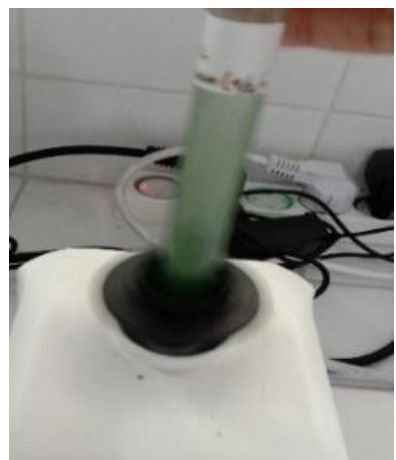

b.

Figure 3. Preparation before spores counting, (a.) Serial dilution of Trichoderma spp. isolate $\left(10^{0}-10^{-4}\right)$, (b.) Homogenization process by using vortex

To calculate the spore density, a dilution of $10^{-2}$ was used to facilitate the observation and calculation process. Some support tools such as Neubauer Improve type hemocytometer, light microscope at 400x magnification, and hand counter were used to calculate spore density. The provision for calculating spore density refers to the protocol of SNI 8027.3:2014 Appendix C pages 6-9 concerning the Conidium Density Test. The spore count was carried out on two hemocytometer fields, each field counted 5 squares diagonally, and carried out three replications. Each replication was counted the number of spores and averaged. An illustration of the spore count according to Indonesia (2014) is shown in Figure 4 (a-b).
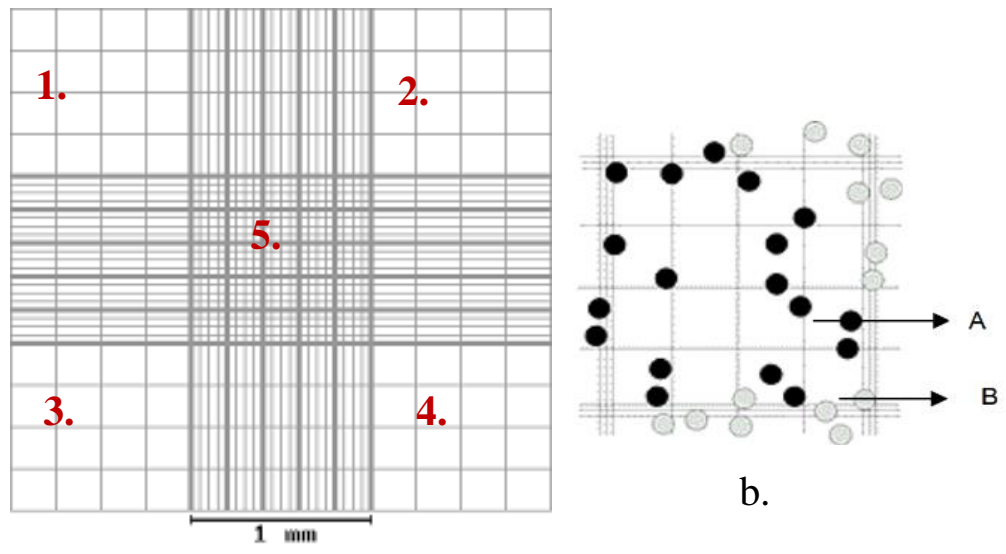

b.

a.

Figure 4. Procedure for calculating spore density. (a.) Five diagonal squares for spore counting. Box number 5 has an area of $1 \mathrm{~mm}^{2}$ divided into 25 squares, so boxes a, b, c, d, e each have an area of 0.04 $\mathrm{mm}^{2}$ (b.) Spores to count (A) and not counted (B). The borders of the right and bottom are not counted.

The spore densities were counted refer to Indonesia (2014),

$S=\frac{X}{L\left(\mathrm{~mm}^{2}\right) \times \mathrm{t}(\mathrm{mm}) \mathrm{xd}} \times 10^{3}$

$\mathrm{S}$ is the abbreviation of spores density (spores $/ \mathrm{mL}$ ); $\mathrm{X}$ is the number of spores in boxes $a, b, c, d, e ; L$ is the area of the calculated box; $t$ is the calculated depth of field; $d$ is the dilution factor; $10^{3}$ is the calculated suspension volume. 
The series of dilutions that must be tested were determined according to the desired number of spores, namely $10^{7}, 10^{5}$, and $10^{3}$ spores $/ \mathrm{mL}$. The three dilution series of Trichoderma spp. were tested for an antagonist with pathogenic isolate Fo.

\section{Antagonistic test: dual culture method of Trichoderma spp. versus Fo}

Perpendicular lines were made on the surface of Petri dishes containing PDA. Each Petri dish was measured and marked from the edge of two $\mathrm{cm}$ for the placement of Trichoderma spp isolates. and Fo (Indonesia, 2014). An illustration of the antagonist test is shown in Figure 5.

Tested isolates

a.

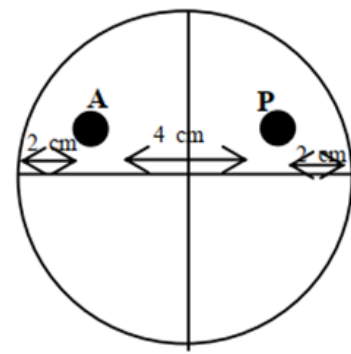

Negative control

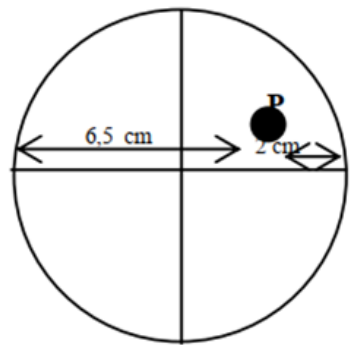

Figure 5. Schematic of placement of Trichoderma spp. antagonistic test. and Fo image was taken from Indonesia (2014). A is an isolate of Trichoderma spp. and P is the isolate of the pathogen Fo.

This antagonistic test used a negative control, Fo.

A Petri dish containing PDA was perforated with a $0.5 \mathrm{~cm}$ diameter cork bore. PDA spheres were taken with a bent needle and placed in each Petri dish exactly at the mark as shown in Figure 5. Each suspension of Trichoderma spp. $\left(10^{7}, 10^{5}\right.$, and $10^{3}$ spores $/ \mathrm{mL})$ were then placed on the PDA sphere as much as one drop $( \pm 0.067 \mathrm{~mL})$. Each treatment was repeated three times. Fo isolate suspension was also placed one drop on the opposite side of Trichoderma spp.. All samples were then incubated at room temperature for seven days. Measurement of the diameter of Fo control and test results were carried out on day three to seven.

The Percentage Inhibition of Radial Growth (PIRG) of each spore density was measured;

PIRG $(\%)=\frac{R 1-R 2}{R 1} \times 100 \%$

$\mathrm{R} 1$ is the radius of Trichoderma spp. as a result of dual culture and R2 is the radius of the negative control.

\section{Statistical Analysis}

Each PIRG data on day seven was analyzed using the RStudio with a one-way ANOVA test at a significance level of $5 \%$ to prove the hypothesis. If there was a difference in response, the Least Significant Difference (LSD) test was carried out to determine the significantly different treatment. 


\section{RESULTS AND DISCUSSION}

\section{Spore densities counting and the serial dilutions to test}

Calculation of spore density is related to the quality of fungal culture, whether it is considered to be effective against pathogens. According to Indonesia (2014), an antagonistic fungus can be considered effective if it has a spore density of $10^{6}$ spores/mL. Trichoderma spp. and Fo isolates were cultivated together so they were expected to have similar physiology and characteristics. The results of the calculation of the spore density of Trichoderma spp. obtained are presented in Table 1.

Table 1. Trichoderma spp. spores density

\begin{tabular}{|c|c|}
\hline Replication & Spores density (spores/mL) \\
\hline I & $9.75 \times 10^{7}$ \\
\hline II & $7.5 \times 10^{7}$ \\
\hline III & $5.5 \times 10^{7}$ \\
\hline Average & $7.58 \times 10^{7}$ \\
\hline
\end{tabular}

The data means that every one $\mathrm{mL}$ sample of Trichoderma spp. isolate contained $7.58 \times 10^{7}$ spores. The spore density was considered as a dilution of $10^{0}$. The next desired spore density was $10^{5}$ and $10^{3}$ spores $/ \mathrm{mL}$. The spore density of $10^{5}$ spores $/ \mathrm{mL}$ lies in the $10^{-2}$ dilution series, while the spore density of $10^{3}$ spores $/ \mathrm{mL}$ lies in the $10^{-}$ ${ }^{4}$ dilution series. The three dilution series $\left(10^{0}, 10^{-2}, 10^{-4}\right.$ spores $\left./ \mathrm{mL}\right)$ should be tested for antagonists with pathogenic isolates of Fo.

\section{Antagonistic test: inhibition percentages and Trichoderma spp. mode of action}

\subsection{Inhibition percentages of Trichoderma spp. to Fo}

The spore density of $10^{7}$ spores $/ \mathrm{mL}$ began to show antagonistic activity on the third day (Figure 6.).
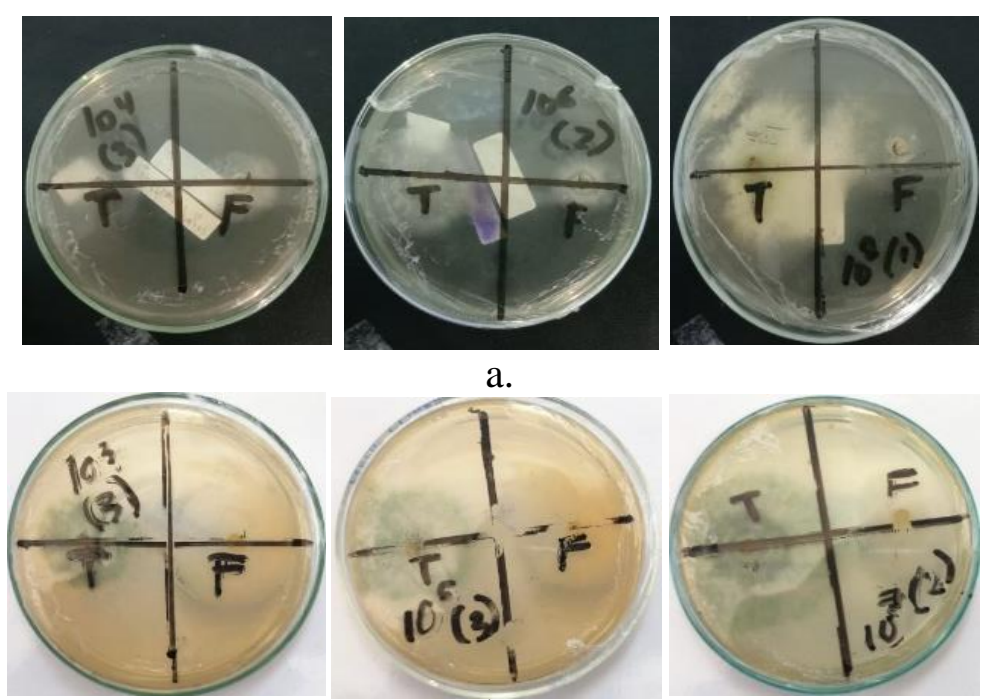

b. 

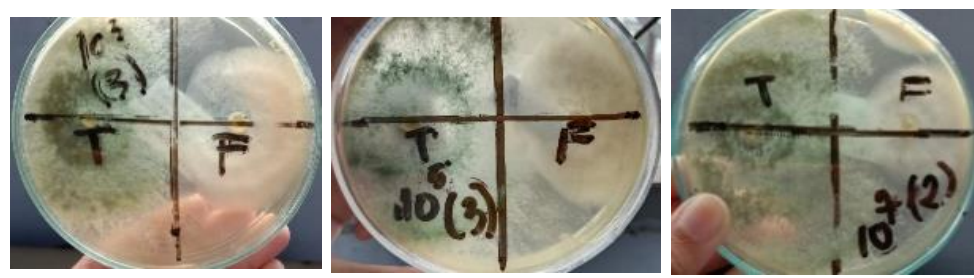

c.
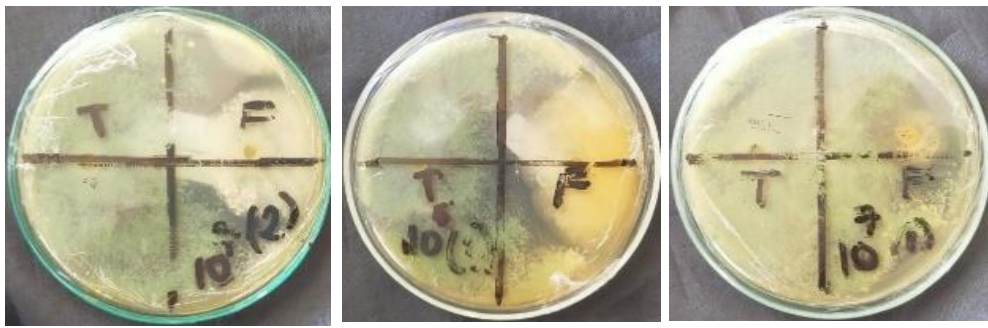

d.
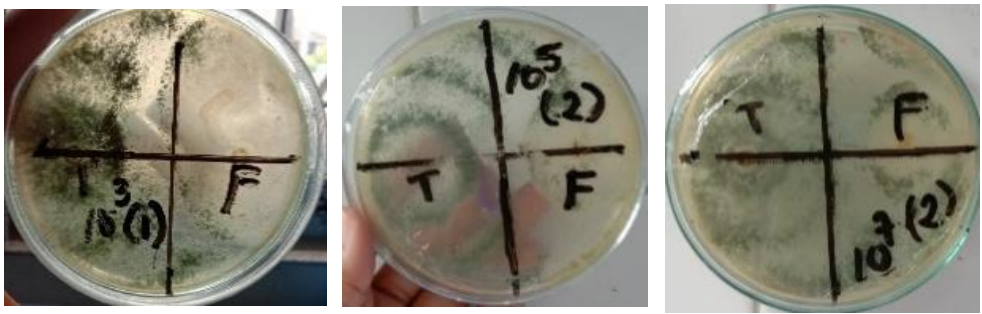

e.

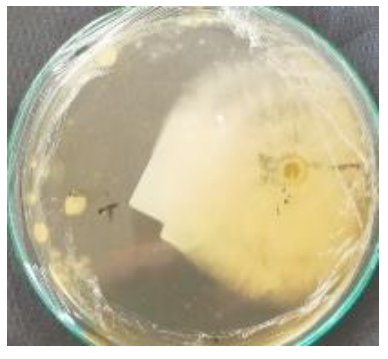

Day six

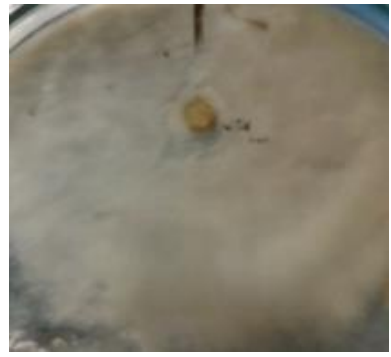

Day seven

f.

Figure 6. Observation of mycelial growth of Trichoderma spp. versus Fo. Each image is arranged sequentially from left to right: spore densities of $10^{3}, 10^{5}$, and $10^{7}$ spores $/ \mathrm{mL}$, (a.) Observations on day three, (b.) Observations on day four, (c.) Observations on day five. 5, (d.) Observation on day six, (e.) Observation on day seven, (f.) Development of Fo control on days six and seven.

There were bacterial contaminants on some Petri dishes. It was caused by either human error or the environment where the treatments were incubated. To overcome this problem, antibacterial compounds may be used in the PDA media.

Figure 6 a shows that the spore density of Trichoderma spp. $10^{3}$ spores $/ \mathrm{mL}$ looked immature and had not shown any antagonistic activity. At a spore density of $10^{5}$ spores/mL, Trichoderma spp. spores turned to mature but there was no visible antagonistic activity. Antagonistic interactions of Trichoderma spp. against Fo began to be seen at a spore density of $10^{7}$ spores $/ \mathrm{mL}$ on day 3 . In Figure 6 , the longer the incubation 
days the diameter of Trichoderma spp. enlarged and showed antagonistic properties against the pathogen Fo. On day seven (Fig. 6e.), three spore densities of Trichoderma spp. began to invade Fo. The data on the percentage of inhibition on day seven along with the LSD test are presented in Table 2.

Generally, Fo infects host plants through three stages, namely adhesion, penetration, and colonization. Fo obtains nutrients from root exudates and the asexual spores adhere to the root surface on day one to two post-inoculation. Then the penetration process is carried out, Fo secretes hydrolysis enzymes to lyse plant cell walls. Fo then secretes pathogenicity factors and host-specific toxins into host cells. Fo reproduces in the cortex and its mycelium begins to infect the vascular system. Conidia and chlamydospores develop and accumulate in the vascular tissue. The conidia quickly spread to all parts of the plant when transpiration occurs. Fo colonizes and damages the vascular tissue, then the mature leaves will be yellowing and over time the plant died (Dita et al., 2018; Rana et al., 2017)

Table 2. PIRG values of Trichoderma spp. to Fo on day seven and their LSD test result

Spore densities

(spores/mL)

PIRG value (\%)*

\begin{tabular}{lc}
\hline $10^{3}$ & $35.27^{\mathrm{b}}$ \\
$10^{5}$ & $44.44^{\mathrm{ab}}$ \\
$10^{7}$ & $54.59^{\mathrm{a}}$
\end{tabular}

*Percentages followed by the same letter notation are not significantly different according to the LSD test at a significance level of $5 \%$.

Based on Table 2., the result shows that the $10^{3}$ spores $/ \mathrm{mL}$ were significantly different from $10^{7}$ spores $/ \mathrm{mL}$. Meanwhile, the percentage of inhibition at spore density of $10^{5}$ spores $/ \mathrm{mL}$ was not significantly different from that of spore density of $10^{3}$ spores $/ \mathrm{mL}$ and $10^{7}$ spores $/ \mathrm{mL}$.

An inhibition zone between Trichoderma spp. and Fo was observed as the result of the antagonistic test and is presented in Figure 7.

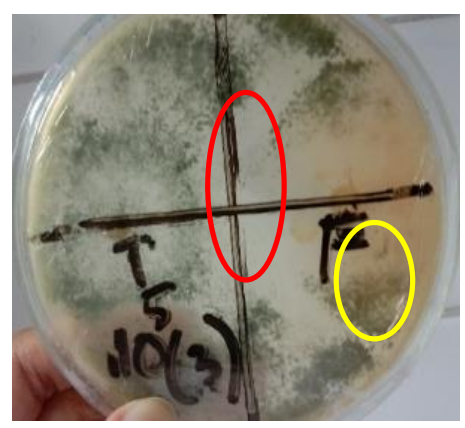

Figure 7. The antagonistic activity of Trichoderma spp. against Fo. The red mark indicates the presence of a clear zone of Trichoderma spp. and the yellow mark indicates an invasion of Trichoderma spp. against Fo.

Trichoderma spp. has abilities to do three main antagonistic mechanisms, namely antibiosis, nutrient grabbing, and mycoparasitism. These three mechanisms work together in inhibiting the growth of Fo. The antifungal ability of Trichoderma spp. has been investigated since the 1930s (Khare et al., 2018). Antibiosis activity can be observed through the formation of a clear zone due to the secretion of secondary metabolites. Based 
on the Vinale et al. (2014) research, secondary metabolites which are secreted by Trichoderma spp. and toxic to Fo including pyrone, koninginins, viridins, and peptaibols.

The third antagonistic mechanism is mycoparasitism activity against Fo. This fungus will form a hook and appresorium structure and then begin to penetrate the target cell wall by secreting lytic enzymes such as glucanase, chitinase, and proteases. The enzymes $1,4-\beta$-acetylglucosamide, endo, and exochitinase are secreted by Trichoderma spp. to improve its biocontrol capability. The $\beta$-glucanase enzyme can degrade $\beta$-glucan as a structural component of pathogens. This process will inhibit the growth and metabolism of phytopathogenic fungi (Mukhopadhyay \& Kumar, 2020).

\section{CONCLUSION}

The spores density of $10^{7}$ spores $/ \mathrm{mL}$ presents the highest inhibition compared with other spore densities yet it is not significantly different with $10^{5}$ spores $/ \mathrm{mL}$ of Trichoderma spp. The spores density of $10^{7}$ spores $/ \mathrm{mL}$ has $54.59 \%$ inhibition and fulfills the minimum standard of PIRG that is more than 50\%. Spore densities have an effect on the inhibition percentage value of Trichoderma spp. against Fo. In vivo test is needed to prove this research results and it may be a good way to formulate the best Trichoderma spp. biopesticide for controlling Fusarium wilt.

\section{REFERENCES}

Badan Pusat Statistik. (2020a). Komoditas Penyumbang Inflasi Terbesar 2019. BPS. https://surakartakota.bps.go.id/indicator/3/220/1/komoditas-penyumbang-inflasiterbesar.html

Badan Pusat Statistik. (2020b). Produksi Cabai Rawit (Kuintal)2017-2019. BPS. https://blorakab.bps.go.id/indicator/55/202/1/produksi-cabai-rawit.html

Bhat, M. N., Mesta, R., Yenjerappa, S. T., Tatagar, M. H., Sardana, H. R., Singh, D., Vennila, S., Sabir, N., \& Ahmad, M. (2016). Biological control of Fusarium wilt of chillies using Trichoderma spp. Indian Journal of Horticulture, 73(1), 74-77. https://doi.org/10.5958/0974-0112.2016.00021.9

Chaverri, P., Branco-rocha, F., Jaklitsch, W., Gazis, R., Degenkolb, T., \& Samuels, G. J. (2016). Systematics of the Trichoderma harzianum species complex and the reidentification of commercial biocontrol strains. Mycologia, 107(3), 558-590. https://doi.org/10.3852/14-147.Systematics

Chaverri, P., \& Samuels, G. J. (2013). Evolution Of Habitat Preference And Nutrition Mode In A Cosmopolitan Fungal Genus With Evidence Of Interkingdom Host Jumps And Major Shifts In Ecology. Evolution, 67(10), 2823-2837. https://doi.org/10.1111/evo.12169

de Lamo, F. J., \& Takken, F. L. W. (2020). Biocontrol by Fusarium oxysporum Using Endophyte-Mediated Resistance. Frontiers in Plant Science, 11, 1-15. https://doi.org/10.3389/fpls.2020.00037

Dita, M., Barquero, M., Heck, D., Mizubuti, E. S. G., \& Staver, C. P. (2018). Fusarium wilt of banana: Current knowledge on epidemiology and research needs toward 
sustainable disease management. Frontiers in Plant Science, 9, 1-21. https://doi.org/10.3389/fpls.2018.01468

Edel-Hermann, V., \& Lecomte, C. (2019). Current Status of Fusarium oxysporum Formae Speciales and Races. Phytopathology, 109(4), 512-530. https://doi.org/10.1094/PHYTO-08-18-0320-RVW

Fourie, G., Steenkamp, E. T., Ploetz, R. C., Gordon, T. R., \& Viljoen, A. (2011). Current status of the taxonomic position of Fusarium oxysporum formae specialis cubense within the Fusarium oxysporum complex. Infection, Genetics and Evolution, 11, 533-542. https://doi.org/10.1016/j.meegid.2011.01.012

Holmes, L., Mandjiny, S., \& Upadhyay, D. (2016). Biological Control of Agriculture Insect Pests. European Scientific Journal, 12(10), 216-225.

Indonesia, B. S. N. (2014). Agens pengendali hayati (APH) - Bagian 3 :

Khan, K. A., Nabi, S. U., Bhat, N. A., \& Bhat, F. A. (2018). Chilli Wilt Disease: A Serious problem in Chilli cultivation in India. Indian Farmer, 5(09), 988-991.

Khare, E., Kumar, S., \& Kim, K. (2018). Role of peptaibols and lytic enzymes of Trichoderma cerinum Gur1 in biocontrol of Fusarium oxysporum and chickpea wilt. Environmental Sustainability, 1(1), 39-47. https://doi.org/10.1007/s42398-0180001-7

Li, Y., Sun, R., Yu, J., Saravanakumar, K., \& Chen, J. (2016). Antagonistic and Biocontrol Potential of Trichoderma asperellum ZJSX5003 Against the Maize Stalk Rot Pathogen Fusarium graminearum. Indian Journal of Microbiology, 56(3), 318327. https://doi.org/10.1007/s12088-016-0581-9

Mariyono, J., \& Sumarno, S. (2015). Chilli production and adoption of chilli-based agribusiness in Indonesia. Journal of Agribusiness in Developing and Emerging Economies, 5(1), 57-75. https://doi.org/10.1108/jadee-01-2014-0002

Moosa, A., Sahi, S. T., Haq, I. U., Farzand, A., Khan, S. A., \& Javaid, K. (2017). Antagonistic Potential of Trichoderma Isolates and Manures Against Fusarium Wilt of Tomato. International Journal of Vegetable Science, 23(3), 207-218. https://doi.org/10.1080/19315260.2016.1232329

Mukhopadhyay, R., \& Kumar, D. (2020). Trichoderma: a beneficial antifungal agent and insights into its mechanism of biocontrol potential. Egyptian Journal of Biological Pest Control, 30(133), 1-8. https://doi.org/10.1186/s41938-020-00333-X

Oljira, T., \& Berta, S. (2020). Isolation and Characterization of Wilt-Causing Pathogens of Local Growing Pepper (Capsicum annuum L.) in Gurage Zone, Ethiopia. International Journal of Agronomy, 2020, 1-8. https://doi.org/10.1155/2020/6638683

Pratiwi, B. N., Sulistyowati, L., Muhibuddin, A., \& Kristini, A. (2013). Uji Pengendalian Penyakit Pokahbung (Fusarium moniliformae) pada Tanaman Tebu (Saccharum 
officinarum) Menggunakan Trichoderma sp. Indigenous Secara In Vitro dan In Vivo. Hama Dan Penyakit Tumbuhan, 1(3), 119-130.

Rana, A., Sahgal, M., \& Johri, B. N. (2017). Fusarium oxysporum: Genomics, diversity and plant-host interaction. In Developments in Fungal Biology and Applied Mycology. https://doi.org/10.1007/978-981-10-4768-8_10

Suryanto, D. W. I., Patonah, S. I. T. I., \& Munir, E. (2010). Control of Fusarium Wilt of Chili With Chitinolytic Bacteria. HAYATI Journal of Biosciences, 17(1), 5-8. https://doi.org/10.4308/hjb.17.1.5

Vinale, F., Sivasithamparam, K., Ghisalberti, E. L., Woo, S. L., Nigro, M., Marra, R., Lombardi, N., Pascale, A., Ruocco, M., Lanzuise, S., Manganiello, G., \& Lorito, M. (2014). Trichoderma Secondary Metabolites Active on Plants and Fungal Pathogens. The Open Mycology Journal, 8(1), 127-139. https://doi.org/10.2174/1874437001408010127

Wolfgang, A., Taffner, J., Guimarães, R. A., Coyne, D., \& Berg, G. (2019). Novel Strategies for Soil-Borne Diseases: Exploiting the Microbiome and Volatile-Based Mechanisms Toward Controlling Meloidogyne-Based Disease Complexes. Frontiers in Microbiology, 10(JUN), 1-15. https://doi.org/10.3389/fmicb.2019.01296 